\title{
EFFECT OF FERTILIZATION AND HUMIC ACID TREATMENTS ON SEEDS PRODUCTION OF PLANTAGO PSYLLIUM L.
}

\author{
Rania M. Khater* and Waleed M. Abd El-Azim \\ Department of Medicinal and Aromatic Plants, Desert Research \\ Center, El-Matareya, Cairo, Egypt \\ *E-mail: dr.raniakhater@yahoo.com
}

7 his experiment was carried out during two consecutive

Research Station of the Desert Research Center, North

Sinai Governorate, to study the effect of different rates of chemical fertilization (control without fertilization, 25, 50 and $75 \%$ of recommended rates) with different levels of humic acid (0,2 and 4 $\mathrm{kg} /$ feddan) and their interaction, on the growth, seed yield, active ingredient and chemical constituents of Plantago psyllium L. plants. The treatment of chemical fertilizers gave significant effect on the plant height, number of branches per plant, the fresh and dry weights per plant, seeds yield per plant and per feddan also mucilage content and percentage per plant and per feddan. The treatment of $75 \%$ from the recommended dose gave the beast result. Treatment as well as humic acid gave significant effect for data recorded and the best treatment was obtained by adding humic acid at a level of 4 $\mathrm{kg} / \mathrm{feddan}$. The obtained results indicated that the interaction between chemical fertilizers at $75 \%$ from the recommended dose combined with addition of humic acid at $4 \mathrm{~kg} / \mathrm{feddan}$ gave a significant effect for all data recorded.

Keywords: Plantago psyllium, L., chemical fertilization, humic acid, seed yield, mucilage

Plantago psyllium L. belongs to the Family Psylliuminaceae. It contains a good percentage of carbohydrates, rich in $\beta$-carotene, linoleic acid, oleic acid and oxalic acid. Seeds contain certain nutrients, such as $\mathrm{Cr}$, $\mathrm{Co}, \mathrm{Ca}, \mathrm{Mg}, \mathrm{Mn}, \mathrm{P}, \mathrm{K}, \mathrm{Na}, \mathrm{Zn}$ and some vitamins such as riboflavin, thiamine, niacin and ascorbic acid and high fiber percentage (Zargari, 1993).

The plant has medicinal importance due to its mucilage; the main component found in seeds. There are many uses of the mucilage, but the most important use is to overcome chronic diarrhea and dysentery by relieving irritation, and also to treat kidney and bladder complaints, gonorrhea, urethritis and hemorrhoids. P. pysllium seeds are used to soften the skin and strengthen hair follicles as well. These seeds also help one lose 
weight because it helps the absorption of cholesterol, excess fat, toxic waste and heavy metals from the body to the outside of the gastrointestinal tract (Koocheki et al., 2007).

The fertilization is the most important influencing factor in improving and increasing agricultural crop yields, especially under reclamation land conditions. Excessive chemical fertilizers has become a threat to the lives of citizens as a result of unjust and indiscriminate use by peasants, behind the negative impacts on the environment and the health of humans and animals (Subba Rao, 1984), so it is important to decrease the use of chemical fertilizers.

Humic acids are considered organic acids that are naturally produced in the organic matter in the soil. The humic acids are used to improve plant growth by improving absorption of elements and making them available to plant. Humic acids improve plant hormones and responsiveness as they inhibit the activity of IAA oxidase, leading to increase activity of the IAA hormone, which encourages plant growth. Also, they have a similar effect to auxins, which encourage root growth (Tatini et al., 1991 and Çimrin et al., 2010) as humic acid works to improve the physical, chemical and biological properties of soil and reduces the salinity problems and damage of water and soil. It is also working to minimize the effect of water stress on the plant and thus increases the ability of the root system of plants to absorb nutrients (Shaaban et al., 2009).

Therefore, the present work was carried out to study the effect of chemical fertilizer rates as well as different humic acid levels aiming to the highest seeds production, which have more mucilage of $P$. pysllium plants.

\section{MATERIALS AND METHODS}

This experiment was carried out during the two successive seasons of 2014/2015 and 2015/2016 at Baluza Research Station of the Desert Research Center, North Sinai Governorate. Current study was conducted to determine the effect of chemical fertilizer rates with different humic acid levels and the interaction among them on the growth, yield and active ingredients of $P$. pysllium plants.

The seeds of $P$. pysllium were obtained from the Department of Medicinal and Aromatic plants, Agricultural Research Center, Dokkey, Cairo, Egypt. The seeds were sown on October $12^{\text {th }}$ in both seasons. The physical and chemical analyses of experimental farm soil in Baluza Research Station are shown in table (1).

This experiment included twelve treatments, which were the combinations of four levels of chemical fertilizer rates; i.e. $0,25,50$ and $75 \%$ of the recommended rate (CFR) and three levels of humic acids $(0,2$ and $4 \mathrm{~kg} /$ feddan) The treatments were arranged in a split plot design with three replicates, where chemical fertilizer rates were randomly arranged in 
the main plots and the humic acid levels were randomly distributed in the sub-plots. Each plot $\left(4 \mathrm{~m}^{2}\right)$ contained four rows at $50 \mathrm{~cm}$ apart. The distance between plants were $25 \mathrm{~cm}$ and each plot contained 32 plants (feddan contained 33600 plants). The chemical fertilizer recommended rates for $P$. pysllium are $200 \mathrm{~kg}$ ammonium sulphate $(20.5 \% \mathrm{~N})$ per feddan and $100 \mathrm{~kg}$ potassium sulphate $\left(48 \% \mathrm{~K}_{2} \mathrm{O}\right)$ per feddan (Karimzadeh and Omiddaigi, 2004 and Jajoria et al., 2013). They were divided into three equal partitions and added trench plot after sowing and $100 \mathrm{~kg}$ calcium superphosphate was added during soil preparation with compost of $20 \mathrm{~m}^{3}$ per feddan. The normal agricultural practices were followed in this district.

Table (1). Physical and chemical properties of the experimental soil.

\begin{tabular}{|c|c|c|c|c|c|c|c|c|c|c|c|c|c|c|}
\hline \multicolumn{3}{|c|}{$\begin{array}{c}\text { Particle size } \\
\text { distribution } \\
(\%)\end{array}$} & \multirow{2}{*}{ 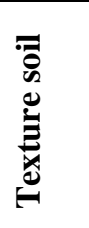 } & \multirow{2}{*}{ 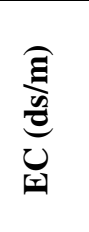 } & \multirow{2}{*}{$\frac{\pi}{2}$} & \multicolumn{5}{|c|}{ Available nutrients (cations) } & \multicolumn{4}{|c|}{ Available nutrients (anions) } \\
\hline : & 券 & $\frac{a}{U}$ & & & & $\begin{array}{l}\mathbf{P} \\
\%\end{array}$ & $\begin{array}{c}\mathrm{Na}^{+} \\
\%\end{array}$ & $\begin{array}{l}\mathbf{K}^{+} \\
\%\end{array}$ & $\begin{array}{c}\mathrm{Ca}^{++} \\
(\mathrm{meg} / \mathrm{l})\end{array}$ & $\begin{array}{c}\mathrm{Mg}^{++} \\
(\mathrm{meg} / \mathrm{l})\end{array}$ & $\mathrm{CO}_{3}^{--}$ & $\begin{array}{l}\mathrm{HCO}_{3}^{-} \\
(\mathrm{meg} / \mathrm{l})\end{array}$ & $\mathrm{SO}_{4}^{--}$ & $\mathrm{Cl}^{-}$ \\
\hline 90 & 5 & 5 & Sand & 1.37 & 8.20 & 0.42 & 4.78 & 0.54 & 3.65 & 4.40 & - & 3.85 & 6.5 & 3.3 \\
\hline
\end{tabular}

The plants received humic acid treatments of 2 or $4 \mathrm{~kg}$ three times; after 30,60 and 90 days from planting as a soil drench. Humic acid was obtained from Tabarak Company for Fertilizers and Chemicals (www.tabarakfert.com).

The following data were recorded:

1. Plant growth: plant height $(\mathrm{cm}$.), number of branches per plant and fresh and dry weights $(\mathrm{g})$ per plant.

2. Yield and production: seed yield (g) per plant and feddan $(\mathrm{kg})$ at harvest date (20 $0^{\text {th }}$ of May).

3. Active ingredients:

- Mucilage percentage was determined according to Anderson (1949) and mucilage content $(\mathrm{g}) /$ plant were calculated by multiplying the mucilage percentage by weight of seeds/plant for each treatment, mucilage content/feddan was calculated by multiplying the mucilage content/plant by number of plants/feddan for each treatment.

- Fixed oil percentage was estimated according to the method of A.O.A.C. (1964).

- Total protein percentage was calculated in either seeds of P. pysllium by multiplying total nitrogen percentage by the factor 6.25 to obtain the percentage of total protein.

4. Chemical constituents determination in $P$. pysllium seeds: total carbohydrate percentage was determined according to Dubios et al. (1956), total nitrogen percentage was determined according to that reported by Naguib (1969), total phosphorus percentage was determined 
according to the methods adapted by Hucker and Catroux (1980) and potassium percentage was determined by using flame photometer according to the method described by Brown and Lilleland (1964).

The recorded data were statistically analyzed and means were compared using least significant difference L.S.D. test at 5\% level according to Snedecor and Cochran (1980) by using computer program of Statistic version 9 (http://www.statistix.com/freetrial.html) Analytical Software (1985).

\section{RESULTS AND DISCUSSION}

\section{Plant Growth}

\subsection{Effect of chemical fertilizer rates}

It is apparent from data in table (2) that the different chemical fertilizer rates recommended (CFR) significantly influenced the plant growth characters; i.e. plant height $(\mathrm{cm})$, number of branches per plant and fresh and dry weights (g/plant) of $P$. pysllium plants during the two seasons, compared to control plants. Moreover, increasing chemical fertilizer rates increased plant growth characters. The application of $75 \%$ of the chemical fertilizer recommended (CFR) recorded the highest value of the plant growth characters.

The simulative effect of chemical fertilizer on different plant growth characters could be explained by increasing metabolic activities that led to increasing cell division and elongation in the meristematic zones of plants under the effect of fertilization treatments. These results are in accordance with those obtained by Abdou et al. (2004) on Foeniculum vulgare Mill., Kandeel (2004) on Ocimum basilicum L. and Gomaa and Youssef (2007a) on Levisticum officinale. They concluded that application of chemical fertilizers to plants significantly increased plant growth characters.

\subsection{Effect of humic acid levels}

Soil drench application of humic acid; i.e. 2 or $4 \mathrm{~kg} / \mathrm{feddan}$ significantly increased plant growth characters; i.e. plant height $(\mathrm{cm})$, number of branches/plant and fresh and dry weights/plant (g) compared to control plants (Table 2).

The maximum values, in this respect, were recorded with 4 $\mathrm{kg} /$ feddan compared with control in both seasons. Otherwise, increasing humic acid levels increased plant growth characters. The enhancement effect of humic acids rate on $P$. pysllium plants growth characteristics may be attributed to increasing the content of the soil nutrients that are available for the growth and stimulate meristems tissue growth by increasing the biological processes related to photosynthesis, which is reflected in the increase in plant height and number of branches, and fresh and dry weight of the plant. The results are in conformity with those reported by Pizzeghello et al. (2001) on Fagus sylvaticae and Nikbakht et al. (2008) on gerbera.

Egyptian J. Desert Res., 66, No. 1, 95-114 (2016) 
Table (2). Effect of chemical fertilizer rates and humic acid levels on the growth of Plantago psyllium L. plant during 2014/2015 and 2015/2016 seasons.

\begin{tabular}{|c|c|c|c|c|}
\hline Characters & $\begin{array}{l}\text { Plant height } \\
\text { (cm) }\end{array}$ & $\begin{array}{c}\text { Number of } \\
\text { branches/plant }\end{array}$ & $\begin{array}{c}\text { Fresh } \\
\text { weight/plant } \\
\text { (g) }\end{array}$ & $\begin{array}{c}\text { Dry } \\
\text { weight/plant } \\
\text { (g) }\end{array}$ \\
\hline \multicolumn{5}{|c|}{ Chemical fertilizer recommended rates (CFR) } \\
\hline \multicolumn{5}{|c|}{ Season 1} \\
\hline Control & 41.63 & 12.41 & 57.62 & 26.26 \\
\hline $25 \%$ CFR & 52.33 & 15.27 & 68.38 & 29.66 \\
\hline 50\% CFR & 59.42 & 17.83 & 78.09 & 33.63 \\
\hline $75 \%$ CFR & 66.59 & 21.75 & 80.22 & 38.16 \\
\hline L.S.D. at $5 \%$ & 1.78 & 0.74 & 1.02 & 1.31 \\
\hline \multicolumn{5}{|c|}{ Season 2} \\
\hline Control & 46.25 & 16.15 & 61.25 & 28.73 \\
\hline $25 \%$ CFR & 53.47 & 18.67 & 70.82 & 33.22 \\
\hline 50\% CFR & 60.63 & 21.17 & 80.30 & 37.66 \\
\hline 75\% CFR & 67.84 & 23.69 & 89.85 & 42.14 \\
\hline L.S.D. at 5\% & 0.49 & 0.17 & 0.65 & 0.31 \\
\hline \multicolumn{5}{|c|}{ Humic acid levels (HAL) } \\
\hline \multicolumn{5}{|c|}{ Season 1} \\
\hline Control & 52.05 & 15.90 & 68.92 & 30.45 \\
\hline $2 \mathrm{~kg} / \mathrm{fed}$ & 54.73 & 16.73 & 70.24 & 31.88 \\
\hline $4 \mathrm{~kg} / \mathrm{fed}$ & 58.20 & 17.82 & 74.08 & 33.45 \\
\hline L.S.D. at $5 \%$ & 1.52 & 0.59 & 0.63 & 1.06 \\
\hline \multicolumn{5}{|c|}{ Season 2} \\
\hline Control & 54.69 & 19.10 & 72.44 & 33.98 \\
\hline $2 \mathrm{~kg} / \mathrm{fed}$ & 56.93 & 19.88 & 75.39 & 35.36 \\
\hline $4 \mathrm{~kg} / \mathrm{fed}$ & 59.52 & 20.79 & 78.83 & 36.98 \\
\hline L.S.D. at $5 \%$ & 0.26 & 0.09 & 0.34 & 0.16 \\
\hline
\end{tabular}

\subsection{Effect of the interaction}

Data in table (3) reveal that, the interaction between different chemical fertilizer and humic acid levels reflected significant effect on plant growth characters. The interaction treatment of $75 \%$ of CFR, when combined with 2 or $4 \mathrm{~kg}$ humic acid/feddan found significantly superior to the rest of combination treatments regarding plant growth characters, it recorded the maximum values of plant growth characters in the first and second seasons. This effect may be due to plant compensation of nutrients by the use of humic acid with chemical fertilizers that impacts on the further growth of the roots by producing auxin for root growth, which has led to the 
production of strong roots able to absorb a lot of nutrients for growth. This reflects on the increase in the rate of photosynthesis and rate meristem tissue division, and thus an increase in the plant growth characters. These results were also reported by El-Bassiony et al. (2010) on snap bean plants.

Table (3). Effect of interaction between chemical fertilizer rates and humic acid levels on the growth of Plantago psyllium L. plant during the 2014/2015 and 2015/2016 seasons.

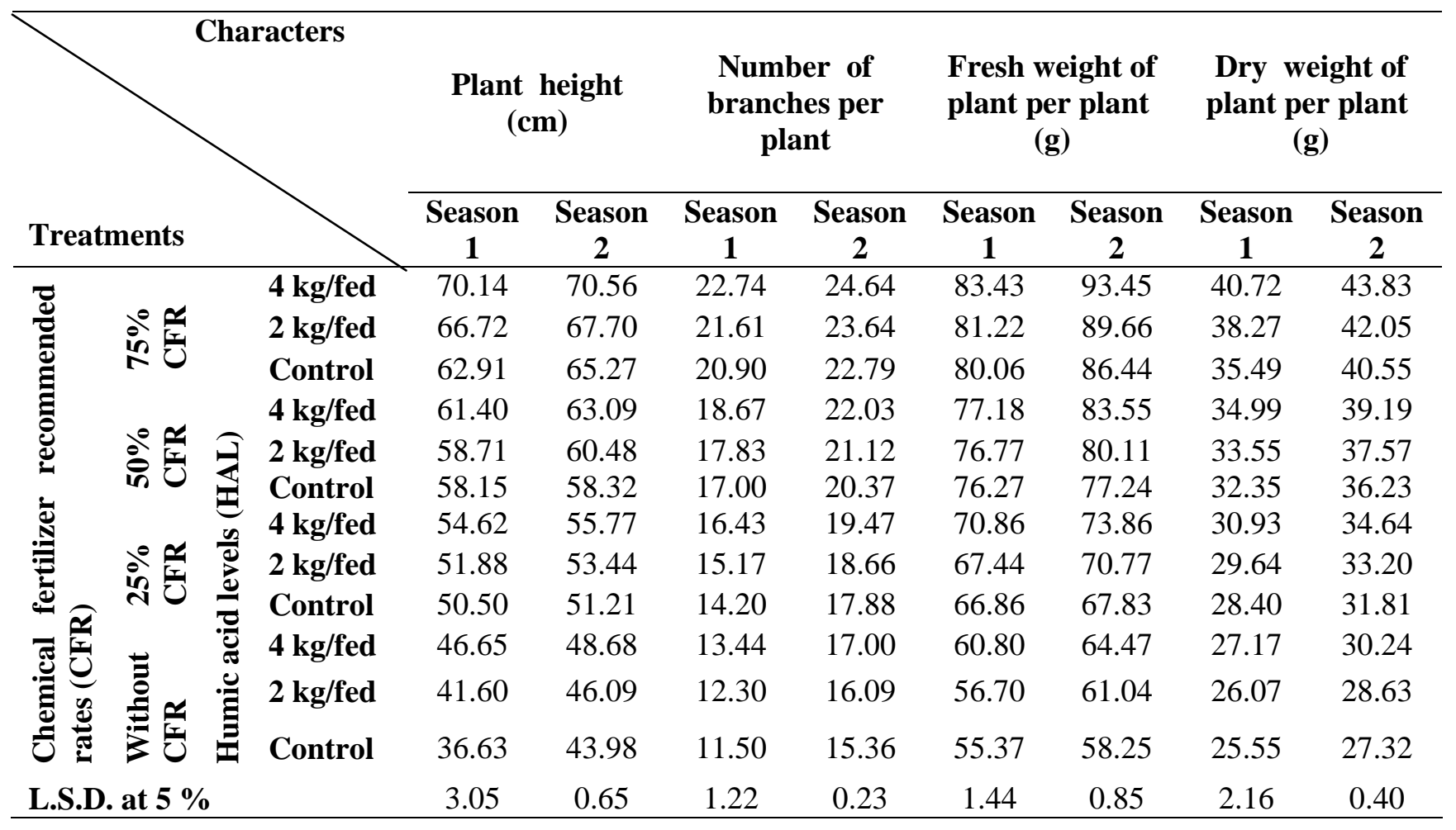

\section{Yield and Production}

\subsection{Effect of chemical fertilizer rates}

Data in table (4) show that chemical fertilizer rates caused a significant increase in all yield and production parameters; i.e. seed yield $(\mathrm{g})$ per plant and feddan $(\mathrm{kg})$. The application at $75 \%$ CFR significantly increased seed yield per plant $(\mathrm{g})$ and feddan $(\mathrm{kg})$ in the first and second seasons. The increase in yield and production of $P$. pysllium plants supplemented with chemical fertilizer rates may be due to the availability of minerals to the plant roots, which ultimately resulted in better root growth and increased mineral absorption that lead to the increase in number of branches/plant and this in turn increased total yield. 
Table (4). Effect of chemical fertilizer rates and humic acid levels on the seed yield per plant $(\mathrm{g})$ and feddan $(\mathrm{kg})$ of Plantago psyllium $\mathrm{L}$. plant during 2014/2015 and 2015/2016 seasons.

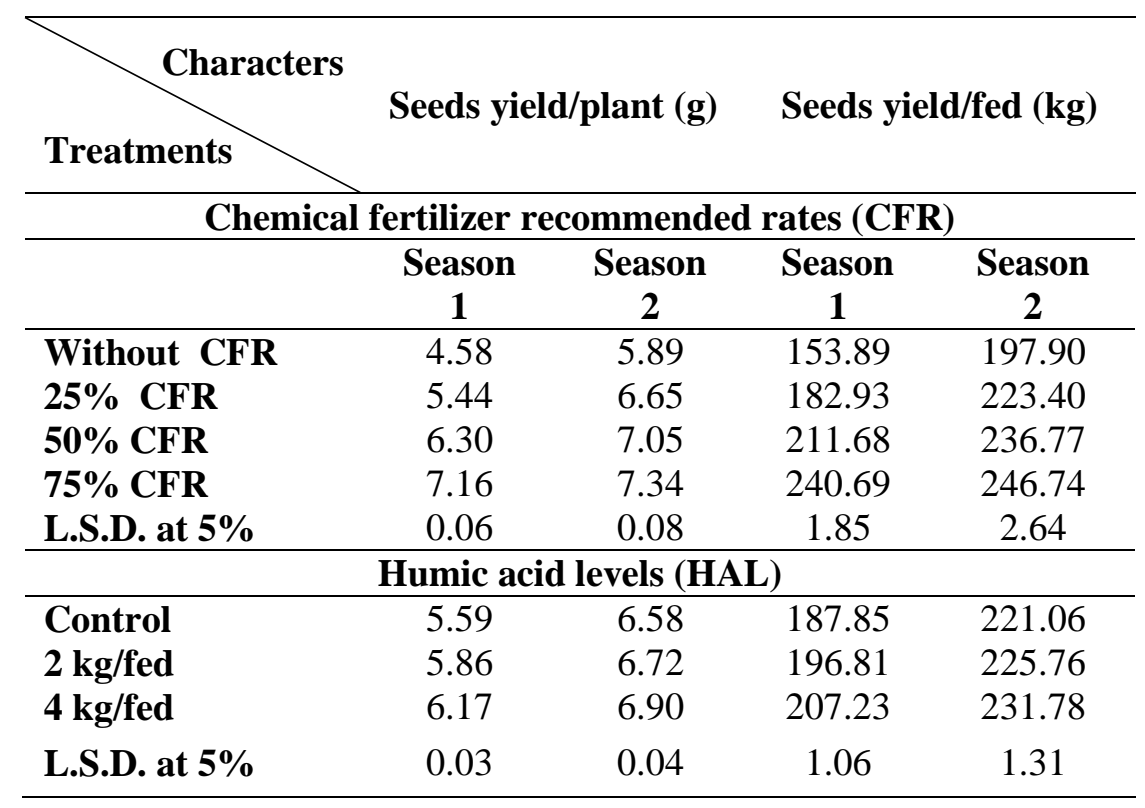

On the other hand, increasing chemical fertilizer rates increased yield and production parameters. These results are in harmony with those obtained by Kandeel et al. (2001) on Foeniculum vulgare Mill., Lee et al. (2005) on Chrysanthemum boreale and Mostafa (2006) on Matricaria chamomilla.

\subsection{Effect of humic acid levels}

Soil drench application on P. psyllium plants with different levels of humic acid significantly increased all studied yield and production parameters; i.e. seed yield per plant (g) and feddan (kg) (Table 4). Since $P$. psyllium plants received 2 or $4 \mathrm{~kg}$ humic acid /feddan were characterized by the highest values of these parameters as compared to control plants. Furthermore, increasing humic acid levels increased yield and production parameters, therefore the application of $4 \mathrm{~kg}$ humic acid /feddan resulted in the highest values of these parameters.

The increment at $P$. psyllium yield may be due to the increase in plant growth parameters (Table 2), which lead to increment of the number of branches per plant that reflected on yield per plant and feddan. The increase in the number of branches per plant treated with humic acid might be due to its role in increasing growth parameters (Table 2).

Sanchez-Sanchez et al. (2002), Abdel-Mawgoud et al. (2007) and Iftikhar et al. (2013) found similar results on lemon trees, tomato and 
gladiolus, respectively, regarding to humic acid soil drench application in improving total yield in the different plants. The simulative effect of humic acid might be attributed to that it contains macro and micro elements, plant growth hormones, high levels of organic matters and fatty acids available to plant, which enhances yield parameters.

\subsection{Effect of the interaction}

It is evident from the data in table (5) that the interaction between chemical fertilizer rates and humic acid levels had significant effect on all yield and production parameters in both seasons of study. The treatment of $75 \%$ CFR with $4 \mathrm{~kg}$ humic acid/ feddan produced the highest values of seed yield, while the lowest seed yield was obtained by control plants.

Table (5). Effect of interaction between chemical fertilizer rates and humic acid levels on the seed yield per plant $(\mathrm{g})$ and feddan $(\mathrm{kg})$ of Plantago psyllium L. during 2014/2015 and 2015/2016 seasons.

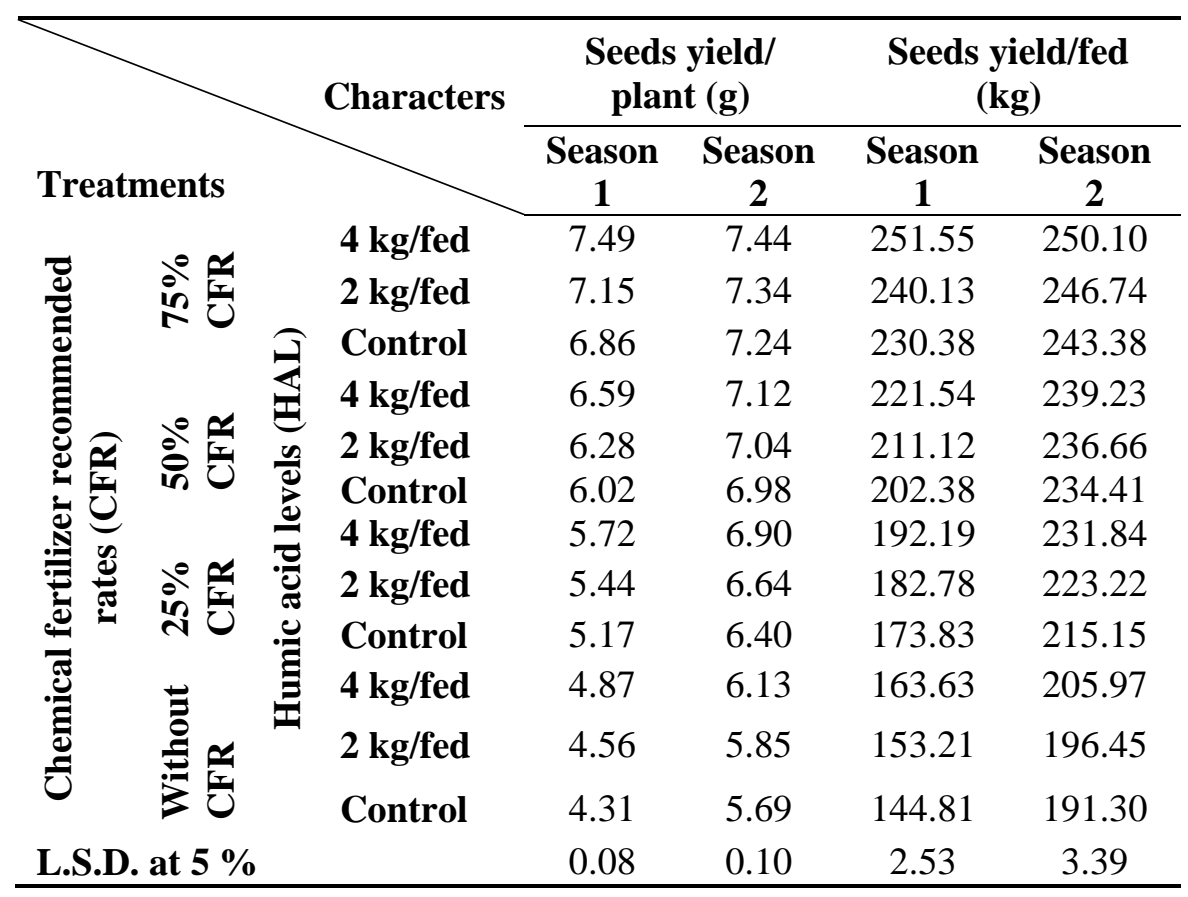

The previous results might be due to the use of humic acid with chemical fertilizers to improve sandy soil structure and increase its ability to retain water. Also, they are working to improve soil fertility and stimulate root growth for increasing the production of auxin, which facilitate the nutrients in soil, and increasing the root absorption of the elements and photosynthesis, which appeared in an increase in the number of branches 
that increase seed yield per plant and feddan. Similar results were obtained by Dileep et al. (2014) on Oryza sativa plant.

\section{Active Ingredients}

\subsection{Effect of chemical fertilizer rates}

Application of chemical fertilizer rates (75\% CFR) significantly enhanced active ingredients characters; i.e. mucilage percentage and mucilage content $(\mathrm{g})$ per plant and per feddan $(\mathrm{kg})$, fixed oil percentage and total protein percentage in both seasons, when compared with control plants, (Table 6). Moreover, increasing chemical fertilizer rates increased these characters. This is may be due to the fact that NPK fertilization caused an increase in photosynthesis process, which in turn stimulates the biosynthesis leading to more branches and seeds yield (as already mentioned in this study for the effect of fertilization) as well as the increase in the active ingredients. These results are in agreement with those found by Badran et al. (2003) on Pimpinella anisum L. and Gomaa and Youssef (2007b) on Foeniculum vulgare Miller. They reported that plant seeds quality were significantly enhanced by increasing the applied rate of chemical fertilizer.

\subsection{Effect of humic acid levels}

Data in table (6) reveal that active ingredients characters; i.e. mucilage percentage and mucilage content per plant $(\mathrm{g})$ and per feddan $(\mathrm{kg})$, fixed oil percentage and total protein percentage were significantly increased due to humic acid soil drench application in both seasons compared with control plants.

In addition, treating $P$. psyllium plants with all humic acid levels, 2 or $4 \mathrm{~kg}$ / feddan significantly increased these parameters in the second season compared to control. On the other hand, increasing humic acid levels increased active ingredients characters, so the application of $4 \mathrm{~kg}$ humic acid/feddan gave the highest values of these parameters.

The increase in active ingredients could be explained by increasing the content of the soil nutrients that led to the increased activity of microorganisms, which led to an increase of plant nutrients that improved the efficiency of photosynthesis. All these effects positively reflected on the plant yield and also increased the active ingredients characters.

These results are in agreement with those reported by Sharif et al. (2002) on maize, Attememe (2009) on Rosmarinus officinalis L., Aydin et al. (2012) on Phaseolus vulgaris L. and Khattab et al. (2012) on pomegranate trees.

\subsection{Effect of the interaction}

Data presented in table (7) show that the interaction between chemical fertilizer rates and humic acid levels had a significantly effect on all studied parameters. It is obvious from the data that the treatment of $75 \%$ CFR with $4 \mathrm{~kg}$ humic acid/feddan gave the highest values of active ingredients characters; i.e. mucilage percentage and mucilage content $(\mathrm{g})$ per 
plant and per feddan $(\mathrm{kg})$, fixed oil percentage and total protein percentage in both seasons of study. So, the physiological activities as photosynthesis and providing plants by nutrients could be the reasons for increasing active ingredients characters. The availability of the crisis for plant growth elements to increase the activity of beneficial microbes in the soil indirectly reflected an increase in the active substances in plant. Similar results were reported by Bama and Selvakumari (2005) on rice plants.

Table (6). Effect of chemical fertilizer rates and humic acid levels on the active ingredients characters of Plantago psyllium L. plant during 2014/2015 and 2015/2016 seasons.

\begin{tabular}{|c|c|c|c|c|c|}
\hline Characters & $\begin{array}{l}\text { Mucilage } \\
\text { percentage }\end{array}$ & $\begin{array}{c}\text { Mucilage } \\
\text { content per } \\
\text { plant (g) }\end{array}$ & $\begin{array}{c}\text { Mucilage } \\
\text { content } \\
\text { per fed }(g)\end{array}$ & $\begin{array}{l}\text { Fixed oil } \\
\text { percentage }\end{array}$ & $\begin{array}{c}\text { Total } \\
\text { protein } \\
\text { percentage }\end{array}$ \\
\hline \multicolumn{6}{|c|}{ Chemical fertilizer recommended rates (CFR) } \\
\hline \multicolumn{6}{|c|}{ Season 1} \\
\hline Without CFR & 16.38 & 0.75 & 25.25 & 10.09 & 14.62 \\
\hline 25\% CFR & 18.76 & 1.02 & 34.36 & 11.46 & 16.57 \\
\hline $50 \%$ CFR & 21.13 & 1.33 & 44.79 & 12.81 & 18.44 \\
\hline $75 \%$ CFR & 23.53 & 1.69 & 56.70 & 14.20 & 20.28 \\
\hline L.S.D. at $5 \%$ & 0.15 & 0.02 & 0.67 & & 0.28 \\
\hline \multicolumn{6}{|c|}{ Season 2} \\
\hline Without CFR & 16.36 & 0.96 & 32.41 & 10.01 & 14.83 \\
\hline 25\% CFR & 18.99 & 1.26 & 42.47 & 11.51 & 17.13 \\
\hline 50\% CFR & 21.58 & 1.52 & 51.10 & 13.00 & 20.00 \\
\hline 75\% CFR & 24.21 & 1.78 & 59.76 & 14.51 & 22.11 \\
\hline L.S.D. at $5 \%$ & 0.21 & 0.03 & 0.92 & 0.10 & 0.40 \\
\hline \multicolumn{6}{|c|}{ Humic acid levels (HAL) } \\
\hline \multicolumn{6}{|c|}{ Season 1} \\
\hline Control & 19.17 & 1.10 & 36.84 & 11.69 & 16.81 \\
\hline $2 \mathrm{~kg} / \mathrm{fed}$ & 19.91 & 1.19 & 40.05 & 12.12 & 17.53 \\
\hline $4 \mathrm{~kg} / \mathrm{fed}$ & 20.78 & 1.31 & 43.94 & 12.61 & 18.09 \\
\hline L.S.D. at $5 \%$ & 0.09 & 0.01 & 0.38 & 0.06 & 0.17 \\
\hline \multicolumn{6}{|c|}{ Season 2} \\
\hline Control & 19.43 & 1.29 & 43.51 & 11.77 & 17.84 \\
\hline $2 \mathrm{~kg} / \mathrm{fed}$ & 20.24 & 1.38 & 46.24 & 12.23 & 18.37 \\
\hline $4 \mathrm{~kg} / \mathrm{fed}$ & 21.18 & 1.47 & 49.56 & 12.77 & 19.34 \\
\hline L.S.D. at 5\% & 0.10 & 0.01 & 0.37 & 0.05 & 0.20 \\
\hline
\end{tabular}




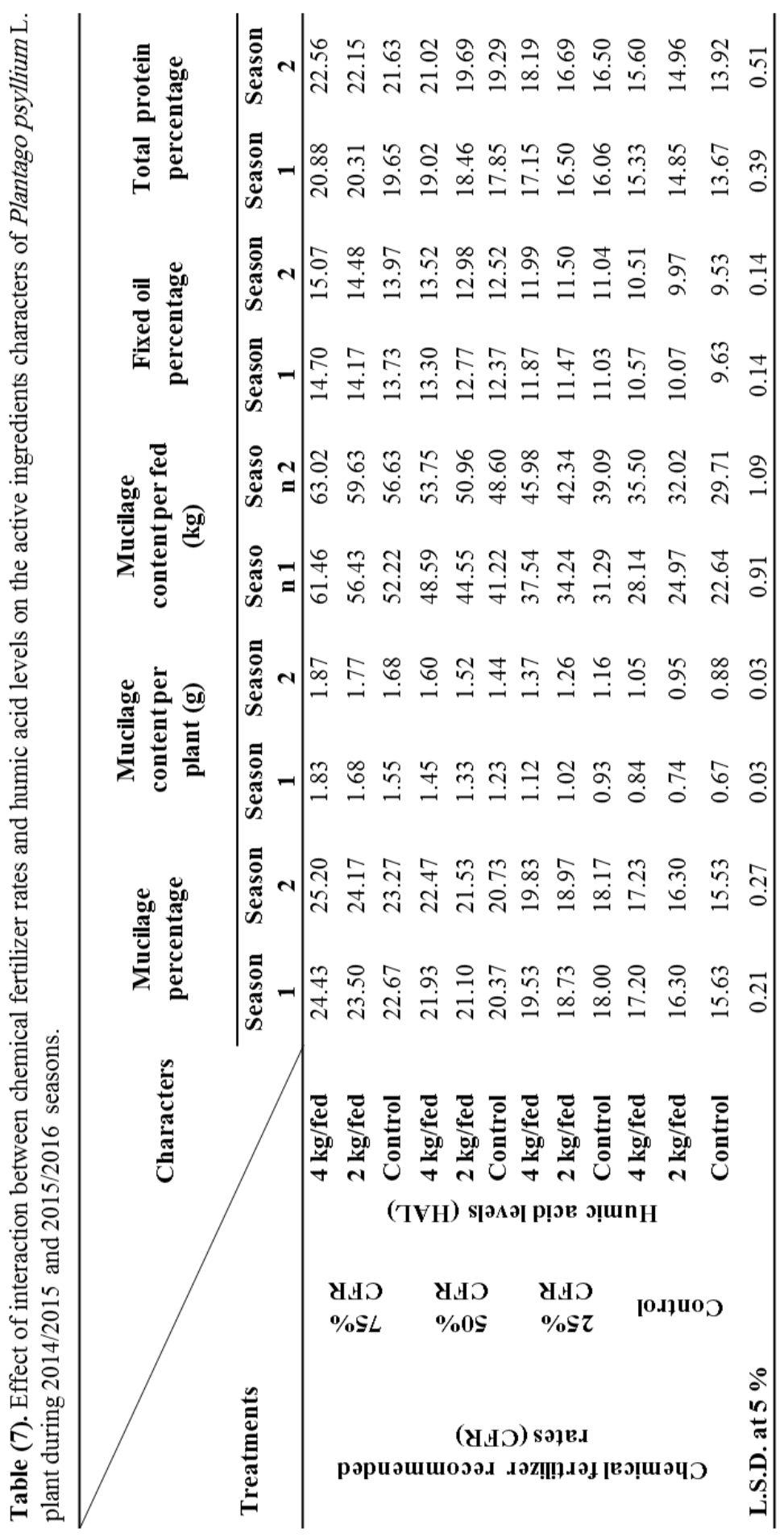

Egyptian J. Desert Res., 66, No. 1, 95-114 (2016) 


\section{Chemical Composition and Total Carbohydrates in $P$. pysllium Seeds 4.1. Effect of chemical fertilizer rates}

Data in table (8) show that application of chemical fertilizer rates at $75 \%$ on $P$. psyllium plants significantly increased nitrogen, phosphorous, potassium and total carbohydrate in seeds compared to control and other treatments. The increment in chemical composition and total carbohydrates resulted from the NPK fertilization treatments might be directly or indirectly due to the activation of the nutrients and carbohydrates metabolism. These nutrients participate in chlorophyll anabolism, leading to more chlorophyll content, which participates directly in nutrients and carbohydrates metabolism. Similar results were also obtained by Nofal et al. (2001) on Ammi visnaga L., Safwat and Badran (2002) on cumin plants and Niakan et al. (2004) on Mentha piperita L. They found that the plant content of NPK and total carbohydrates is significantly increased by increasing chemical fertilizer rates.

\subsection{Effect of humic acid levels}

Soil drench application of 2 or $4 \mathrm{~kg}$ humic acid/feddan significantly increased nitrogen, potassium and total carbohydrates percentages in $P$. psyllium seeds. On the other hand, application of different humic acid levels to plants increased all these parameters under study. While, application of different humic acid levels to $P$. psyllium plants did not reflect any significant effect on phosphorus percentage in seeds (Table 8).

These results are supported with those reported by Sanchez-Sanchez et al. (2002) on lemon trees and Ashraf et al. (2005) on Vigna radiate L. They found that soil drench plants with humic acid levels showed increase in nitrogen, phosphorus, potassium and total carbohydrates percentages. The effect of humic acid on improving biochemical characters of seed protein content was reported by Aydin et al. (2012) on Phaseolus vulgaris L. It is obvious from the same data in table (7) that the soil drench application of 2 and $4 \mathrm{~kg}$ humic acid/feddan increased significantly.

The obtained results are in accordance with those previously recorded by Cangi et al. (2006) on Vitis vinifera L. and Rajpar et al. (2011) on Brassica comestris L., who reported that humic acid contains organic matters, which induce the physiological activities and increase total chlorophyll in plants. This will positively reflect in the activity of photosynthesis and the synthesized materials that will positively reflect on shoots characteristics.

Egyptian J. Desert Res., 66, No. 1, 95-114 (2016) 
Table (8). Effect of chemical fertilizer rates and humic acid levels on the chemical composition and total carbohydrates of Plantago psyllium L. plant during 2014/2015 and 2015/2016 seasons.

\begin{tabular}{|c|c|c|c|c|}
\hline Characters & $\begin{array}{c}\text { Total } \\
\text { nitrogen } \\
\text { percentage }\end{array}$ & $\begin{array}{c}\text { Total } \\
\text { phosphorus } \\
\text { percentage }\end{array}$ & \begin{tabular}{c}
\multicolumn{1}{c}{ Total } \\
potassium \\
percentage
\end{tabular} & $\begin{array}{c}\text { Total } \\
\text { carbohydrate } \\
\text { percentage }\end{array}$ \\
\hline \multicolumn{5}{|c|}{ Chemical fertilizer recommended rates (CFR) } \\
\hline \multicolumn{5}{|c|}{ Season 1} \\
\hline Control & 2.34 & 0.224 & 0.15 & 15.86 \\
\hline $25 \%$ CFR & 2.65 & 0.513 & 0.46 & 18.16 \\
\hline $50 \%$ CFR & 2.95 & 0.818 & 0.75 & 20.57 \\
\hline 75\% CFR & 3.24 & 1.069 & 1.90 & 22.94 \\
\hline L.S.D. at $5 \%$ & 0.05 & 0.031 & 0.02 & 0.23 \\
\hline \multicolumn{5}{|c|}{ Season 2} \\
\hline Control & 2.37 & 0.243 & 1.71 & 17.45 \\
\hline $25 \%$ CFR & 2.74 & 0.536 & 2.14 & 19.97 \\
\hline 50\% CFR & 3.20 & 0.848 & 2.48 & 22.63 \\
\hline 75\% CFR & 3.54 & 1.108 & 2.72 & 25.24 \\
\hline L.S.D. at $5 \%$ & 0.06 & 0.029 & 0.03 & 0.25 \\
\hline \multicolumn{5}{|c|}{ Humic acid levels (HAL) } \\
\hline \multicolumn{5}{|c|}{ Season 1} \\
\hline Control & 2.69 & 0.568 & 0.50 & 18.40 \\
\hline $2 \mathrm{~kg} / \mathrm{fed}$ & 2.81 & 0.656 & 0.91 & 19.29 \\
\hline $4 \mathrm{~kg} / \mathrm{fed}$ & 2.90 & 0.744 & 1.04 & 20.45 \\
\hline L.S.D. at $5 \%$ & 0.03 & 0.015 & 0.02 & 0.31 \\
\hline \multicolumn{5}{|c|}{ Season 2} \\
\hline Control & 2.85 & 0.597 & 2.13 & 20.24 \\
\hline $2 \mathrm{~kg} / \mathrm{fed}$ & 2.94 & 0.688 & 2.29 & 21.22 \\
\hline $4 \mathrm{~kg} / \mathrm{fed}$ & 3.10 & 0.767 & 2.37 & 22.50 \\
\hline L.S.D. at $5 \%$ & 0.03 & 0.016 & 0.03 & 0.34 \\
\hline
\end{tabular}

\subsection{Effect of the interaction}

Data presented in table (9) show that nitrogen, phosphorus, potassium and total carbohydrates percentages in $P$. psyllium seeds were significantly influenced by the interaction between chemical fertilizer rates and humic acid levels. The treatments of $75 \%$ CFR with 2 or $4 \mathrm{~kg}$ humic acid/feddan increased these parameters, but the treatment of $75 \%$ CFR with $4 \mathrm{~kg}$ humic acid/ feddan gave the highest values of tested parameters and this increase is significant in the both seasons. 
The increment in the chemical composition and total carbohydrates in $P$. psyllium seeds could be attributed to the presence of organic material with a chemical fertilizer available in the soil, which led to the possibility of increasing the absorption of crisis elements for plant growth. This increased protein and sugars and carbohydrates representation and thus increases the essential nutrients (NPK) in plant tissues. These results are in agreement with those reported by Shehata et al. (2011) on strawberry plants.

Table (9): Effect of interaction between chemical fertilizer rates and humic acid levels on the chemical composition and total carbohydrates of Plantago psyllium L. plant during 2014/2015 and 2015/2016 seasons.

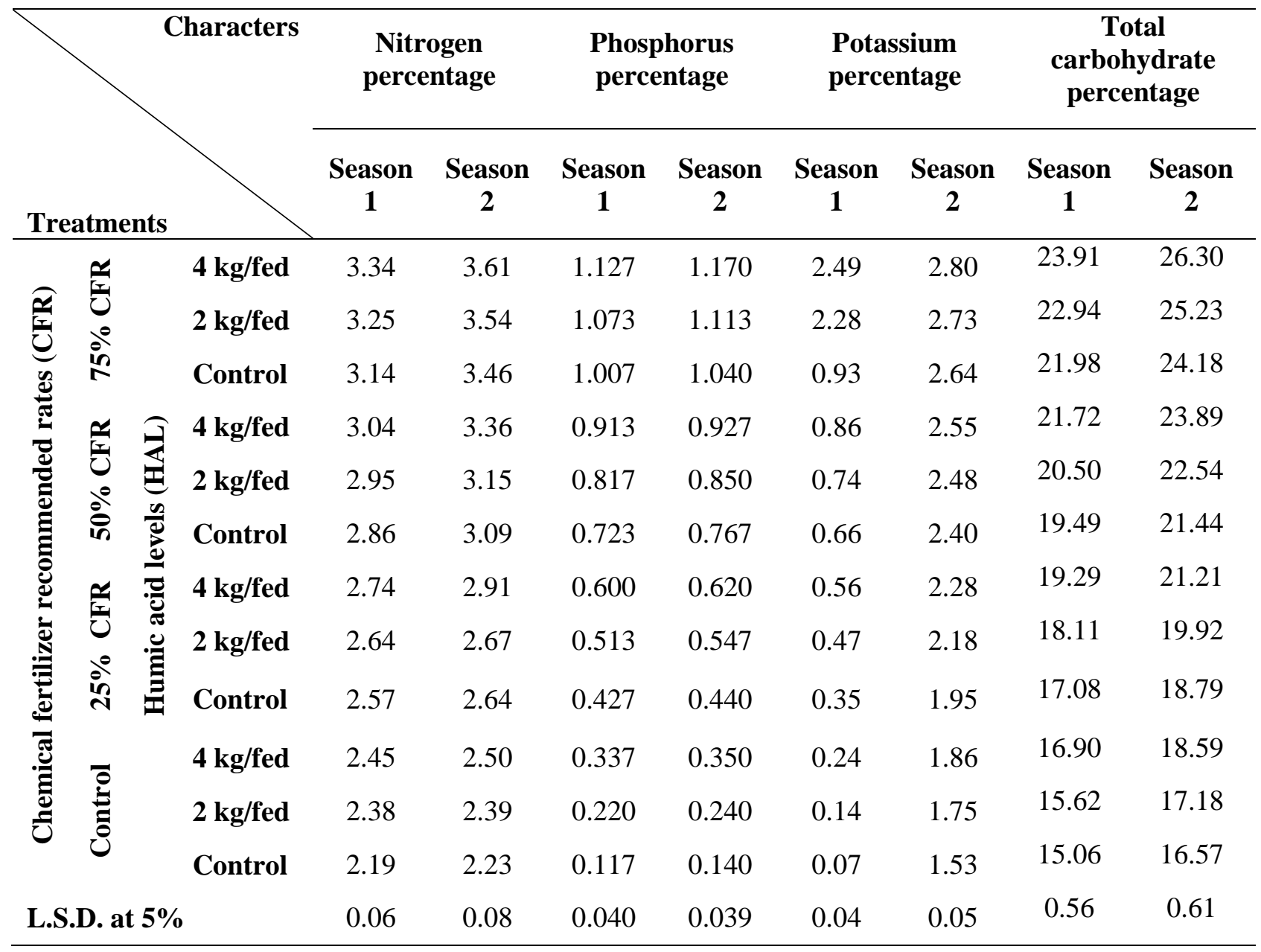




\section{REFERENCES}

Abdel-Mawgoud, A.M.R., N.H.M. El- Greudy, Y. I. Helmy and S.M. Singer (2007). Responses of tomato plants to different rates of humic based fertilizer and NPK fertilization. J. Applied Sci. Research, 3 (2): 169174.

Abdou, M.A.H., A.A. El-Sayed, F.S. Badran and R.M. Salah El-Deen (2004). Effect of planting density and chemical and bio-fertilization on vegetative growth, yield and chemical composition of fennel (Foeniculum vulgare, Miller). II- Effect of NPK chemical fertilization and bio-fertilization treatments. Annals of Agric. Sc., Moshtohor, 42 (4): 1923- 1937.

Analytical Software (1985). Data analysis software for researchers 1985.

Anderson, E. (1949). Endosperm mucilage's of legumes: occurrence and composition. Ind. Eng. Chem., 41: 2887-2890.

A.O.A.C. (1964). In "Official and Tentative Methods of American Oil Chemists" $2^{\text {nd }}$ Ed. Published by the American Oil Chemist's Society, 35, East Wocher Driver Chicago Illinois.

Ashraf, M.W., N. Saqib and T.B. Sarfraz (2005). Biological effect of biofertilizer humic acid on Mung beans (Vigna radiate L.). Journal of Biology and Biotechnology, 2 (3): 737-739.

Attememe, J.Y.A. (2009). The effect of humic acid and seaweed extracts on the growth, chemical characteristics and oil characteristics of Rosmarinus officinalis L. The $6^{\text {th }}$ scientific conference, Biology Dept., College of Education, University of Tikrit. Plants Sci., p. 1-17.

Aydin, A., C. Kant and M. Turan (2012). Humic acid application alleviates salinity stress of bean (Phaseolus vulgaris L.) plants decreasing membrane leakage. African Journal of Agriculture Research, 7: 10731086.

Badran, F.S., F.A. Attia, E.T. Ahmed and H.S. Soliman (2003). Effect of chemical and biological fertilization on growth, yield and oil production of anise (Pimpinella anisum L.) plants. II- Effect of N.P. mineral/bio fertilization and micronutrient treatments. Proc. Egyption Syrian. $1^{\text {st }}$ Conf., Minia Univ.

Bama, K.S. and G. Selvakumari (2005). Effect of humic acid and fertilizers on yield and nutrition of rice in alfisol. J. Ecobiol., 17 (1): 41-47.

Brown, J.D. and O. Lilleland (1964). Rapid determination of potassium and sodium in plant material and soil extracts by flame photometer. Proc. Amer. Soc. Hort. Sci., 48: 341-46.

Cangi, R., C. Tarakcioglu and H. Yasar (2006). Effect of humic acid applications on yield, fruit characteristics and nutrient uptake in Ercis grape (Vitis vinifera L.) cultivar. Asian Journal Chemistry, 18: 14931499. 
Çimrin, K.M., T. Onder, T. Metin and T. Burcu (2010). Phosphorus and humic acid application alleviate salinity stress of pepper seedling. African Journal of Biotechnology, 9 (36): 5845-5851.

Dileep, K.U., A.P. Singh, P. Raha and C.M. Singh (2014). Effects of potassium humate and chemicals fertilizers on growth yield and quality of rice (Oryza sativa L.). Bangladesh J. Bot., 43 (2): 183-189.

Dubios, H., K.A. Gillo, J. Hamillon, R. Robers and I. Smith (1956). Colorimetric method for determination of sugars and related substances. Anal. Chem., 28: 350.

El-Bassiony, A.M., Z.F. Fawzy, M.M.H. Abd El-Baky and A.R. Mahmoud (2010). Response of snap bean plants to mineral fertilizers and humic acid application. Res. J. Agric. Bio. Sci., 6 (2): 169-175.

Gomaa, A.O. and A.S.M. Youssef (2007a). Influence of chemical, organic and bio-fertilizer application on growth and productivity of lovage plant (Levisticum officinale, Koch). Egypt. J. of Appl. Sci., 22 (IIB): 492-520.

Gomaa, A.O. and A.S.M. Youssef (2007b). Bio-fertilizers as a partial alternative to chemical NPK fertilization and its influence on the productivity of fennel plants (Foeniculum vulgare Miller). The Third Conf. of Sustain. Agric. Develop. Fac. Agric., Fayoum Univ., 12-14 Nov., p. 327-352.

Hucker, T.W.G. and G. Catroux (1980). Phosphorus in sewage ridge and animal waste slurries. Proceeding of the EEC Seminar, Haren (Gr), Groningen Netherlands, 12 and 13 June.

Iftikhar, A.U. Saquib, Rana, M. Qasim, M. Saleem, A.S. Khan, and Y. Muhammad (2013). Humic acid and cultivar effects on growth, yield, vase life, and corm characteristics of gladiolus. Chilean J. Agric. Res., 73 (4) Chillán dic.

Jajoria, D.K., A.C. Shivran and G.P. Narolia (2013). Effect of phosphorus and sulphur fertilization on economics of blond psyllium (Plantago ovata Forsk) and optimum doses of fertilizers. Int. J. of Agric. Sci., 9: 678-680.

Kandeel, Y.M.R. (2004). Effect of bio, organic and chemical fertilization on growth, essential oil productivity and chemical composition of Ocimum basilicum L. plant. Annals of Agric. Sci., Moshtohor, 42 (3): 1253-1270.

Kandeel, Y.R., E.S. Nofal, F.A Menesi, K.A. Reda, M. Taher and Z.Y. Zaki (2001). Effect of some cultural practices on growth and chemical composition of some medicinal plants in northern Sinai. 2Foeniculum vulgare Mill. Proc. Fifth Arabian Horticulture Conference, Ismailia, Egypt, March 24-28, p. 61-72.

Karimzadeh, G. and R. Omiddaigi (2004). Growth and seed characteristics of Isabgol (Plantago ovata Forsk) as influenced by some environmental factors. J. Agric. Sci. Technol., 6: 103-110. 
Khattab, M.M., A.E. Shaban, A.H. El-Shrief and A.S. El-Deen Mohamed (2012). Effect of humic acid and amino acid on pomegranate trees under deficit irrigation. I: Growth, flowering, and fruiting. Journal of Horticultural Science and Ornamental Plants, 4: 253-259.

Koocheki, A., L.Tabrizi and M.N. Mahallati (2007). The effects of irrigation intervals and manure on quantitative and qualitative characteristics of Plantago ovata and Plantago psyllium. Asian J. Plant Sci., 6: 12291234.

Lee, K., M. Yang Supanjani and D.L. Smith (2005). Fertilizer effect on the yield and terpene components from the flower heads of Chrysanthemum boreale M. (Compositae). Agronomy for Sustainable Development, 25 (2): 205-211.

Mostafa, H.S. (2006). Effect of some bio-fertilizers compared with chemical fertilizers on growth, yield and active constituents of chamomile plant (Matricaria chamomilla). M. Sc. Thesis, Fac. Agric., Benha Univ., Egypt.

Naguib, M. I. (1969). Colorimeter determination of nitrogen components of plant tissues. Bull. Fac. Sci., Cairo Univ., 43: 1-9.

Niakan, M., R.A. Khavarynejad and M.B. Rezaee (2004). Effects of different rates of NPK fertilizer on the leaf fresh weight, dry weight, leaf area and oil content of Mentha piperita, L. Iranian Journal of Medicinal and Aromatic Plants Research, 20 (2): 131-148.

Nikbakht, A., M. Kafi, M. Babalar, Y.P. Xia, A. Luo, and N. Etemadi (2008). Effect of humic acid on plant growth, nutrient uptake, and postharvest life of gerbera. Journal of Plant Nutrition, 31: 2155-2167.

Nofal, E.S., Y.R. Kandeel, F.A. Menesi, K.A. Reda, M. Taher and Z.T. Zaki (2001). Effect of some cultural practices on growth and chemical composition of some medicinal plants in northern Sinai. 1- Ammi visnaga, L. Proc. $5^{\text {th }}$ Arab. Hort. Conf., Ismailia, Egypt, March 24-28, 2001, p. 51-60.

Pizzeghello, D., G. Nicolini and S. Nardi (2001). Hormone-like activity of humic substances in Fagus sylvaticae forests. New Phytologist, 51: 647-657.

Rajpar, M., B. Bhatti, A. Zia-ul-hassan, A. N. Shah and S. D. Tunio (2011). Humic acid improves growth, yield and oil content of Brassica comestris L. Pakistan Journal of Agriculture-Agricultural Engineering and Veterinary Sciences, 27 (2): 125-133.

Safwat, M.S. and F.S. Badran (2002). Efficiency of organic and biofertilizers, in comparison with chemical fertilization on growth, yield and essential oil of cumin plants. Proc. $9^{\text {th }}$ Conf. of Medical and Aromatic plants. Cairo, Egypt, p. 120-130.

Sanchez-Sanchez, A., J. Sanchez-Andreu, M. Juarez, J. Jorda, and D. Bermudez (2002). Humic substances and amino acids improve 
effectiveness of chelate Fe EDTA in lemon trees. Journal of Plant Nutrition, 25: 2433-2442.

Shaaban, S.H.A, F.M. Manal and M.H.M. Afifi (2009). Humic acid foliar application to minimize soil applied fertilization of surface irrigated wheat. World Journal of Agriculture Sciences, 5 (2): 207 - 210.

Sharif, M., R.A. Khattak, and M.S. Sarir. (2002). Effect of different levels of lignitic coal derived humic acid on growth of maize plants. Communication in Soil Science and Plant Analysis, 33: 3567-3580.

Shehata, S.A., A.A. Gharib, M. Mohamed El-Mogy, K.F. Abdel Gawad and A. Emad Shalaby (2011). Influence of compost, amino and humic acids on the growth, and yield and chemical parameters of strawberries. Journal of Medicinal Plants Research, 5 (11): 23042308.

Snedecor, G.W. and W.G. Cochran (1980). In "Statistical Methods". $7^{\text {th }}$ Ed. Iowa State Univ., Press, Amer., Iowa, USA.

Subba Rao, N.S. (1984). In "Bio-Fertilizers in Agriculture". $3^{\text {rd }}$ Ed. Oxford and IBH Publishing Co., New Delhi, India.

Tatini, M., P. Bertoni, A. Landi and M.L. Traversi (1991). Effect of humic acids on growth and biomass portioning of container-grown olive plants. Acta Hort., 294: 75-80.

Zargari, A. (1993). In "Medicinal Plants". Vol. 4, $4^{\text {th }}$ Ed., Tehran University, Tehran, p. 536-537. 


\section{تأثير التسميد والمعاملة بحامض الهيومك على إنتاجية بذور نبات القاطونة}

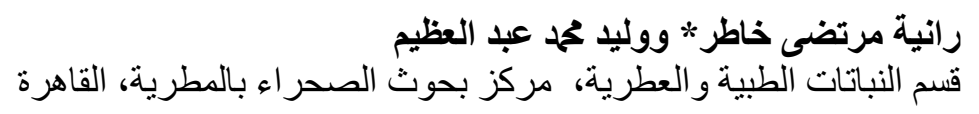

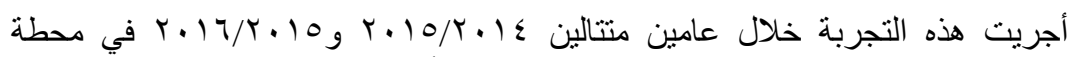

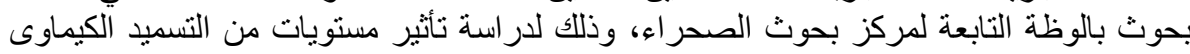

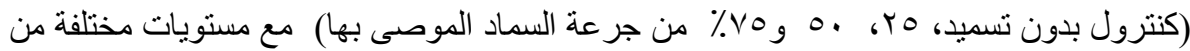

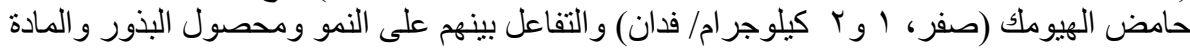

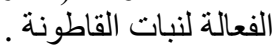

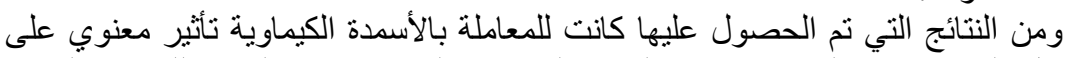

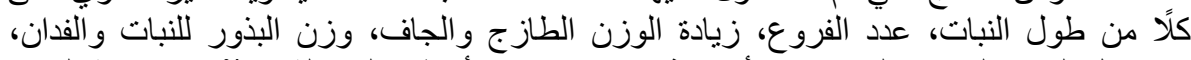

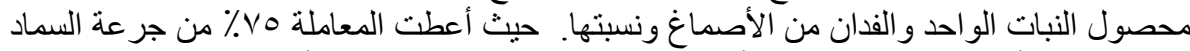

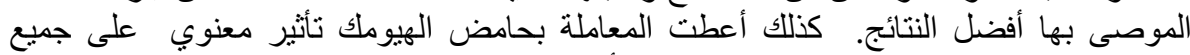

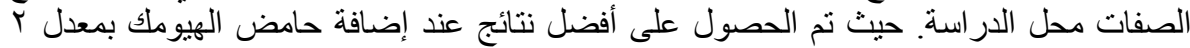

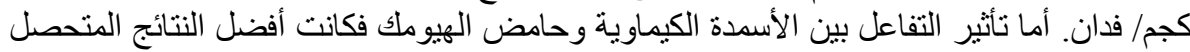

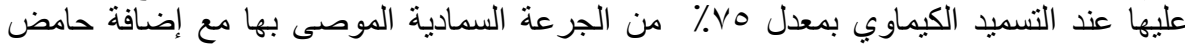

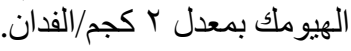

